\title{
Study on Optimization of Must and Fermentation Conditions for Production of Jack Fruit (Artocarpus heterophyllus L.) Wine
}

\author{
S. K. Anil ${ }^{1}$, Praveen Gidagiri ${ }^{2 *}$ and Praveen Jholgikar ${ }^{3}$ \\ ${ }^{1}$ Department of Post-Harvest Technology, College of Horticulture, Arabhavi, India \\ ${ }^{2}$ Department of Post-Harvest Technology, College of Horticulture, Bagalkot, India \\ ${ }^{3}$ Department of Fruit Science, College of Horticulture, Arabhavi, India \\ *Corresponding author
}

\begin{abstract}
A B S T R A C T
The present investigation on Optimization of must and fermentation conditions for production of jack fruit (Artocarpus heterophllyus L.) wine was carried out in the department of Post-Harvest Technology, Kittur Rani Channamma College of Horticulture (University of Horticultural Sciences , Bagalkot), Arabhavi, during the year 2010-2011. It consisting of different treatments viz $\mathrm{T}_{1}-$ Must with $24{ }^{\circ} \mathrm{Brix}$ TSS +3.2 $\mathrm{pH}+1: 2$ dilution, $\mathrm{T}_{2}-$ Must with $24^{\circ} \mathrm{Brix}$ TSS $+3.3 \mathrm{pH}+1: 2$ dilution, $\mathrm{T}_{3}-$ Must with $24^{\circ} \mathrm{Brix}$ TSS +3.4 $\mathrm{pH}+1: 2$ dilution, $\mathrm{T}_{4}-$ Must with $24^{\circ} \mathrm{B}$ rix TSS $+3.5 \mathrm{pH}+1: 2$ dilution, $\mathrm{T}_{5}-$ Must with $24^{\circ} \mathrm{Brix}$ TSS +3.2 $\mathrm{pH}+1: 2.5$ dilution, $\mathrm{T}_{6}-$ Must with $24^{\circ} \mathrm{Brix}$ TSS $+3.3 \mathrm{pH}+1: 2.5$ dilution, $\mathrm{T}_{7}-$ Must with $24^{\circ} \mathrm{Brix}$ TSS +3.4 $\mathrm{pH}+1: 2.5$ dilution and $\mathrm{T}_{8}-$ Must with $24^{\circ} \mathrm{Brix}$ TSS $+3.5 \mathrm{pH}+1: 2.5$ dilution. The experiment was laid out in a completely randomized design with three replications. The main objective was to standardize the optimum level of dilution and $\mathrm{pH}$ in the jack fruit must. Various biochemical and organoleptic quality of wine recorded at regular interval during the storage of wine. The TSS, total sugars, reducing and nonreducing sugar content in all the treatments decreased following fermentation.. The least TSS and sugars were observed in the wine made from must with 1:2.5 dilution $+3.4 \mathrm{pH}\left(\mathrm{T}_{7}\right)$ in the fresh wine as well in the aged wine under cold condition and in must with $1: 2.5$ dilution $+3.5 \mathrm{pH}\left(\mathrm{T}_{8}\right)$ under ambient condition The left over sugars in the fresh wine had a range from $8.86\left(\mathrm{~T}_{8}\right)$ to $10.79\left(\mathrm{~T}_{4}\right)$ per cent respectively. Tannins per cent were showed non-significant difference and decreasing trend can be seemed over period of aging, $\mathrm{T}_{8}$ (must with 1:2.5 dilution $+3.5 \mathrm{pH}$ ) observe the highest per cent of tannins throughout the investigation. The clarity of wine as revealed by maximum transmission (1.56 and 1.67) was noticed in $\mathrm{T}_{8}$ and $\mathrm{T}_{3}$ aged under cold and ambient condition.
\end{abstract}

\section{Introduction}

The fruit is said to grow on the branches, the trunk, and the roots of the tree and looks like stuffed tripe hung all over the tree Jackfruit is quite popular in Eastern and Southern India and is cultivated widely in many states. The total area under jackfruit in India is approximately 1.02 lakh hectares. It is cultivated in an area of about 0.11 lakh hectares mostly in Southern Plains and
Western Ghats of Karnataka producing about 2.6 lakh tonnes of fruits per annum (Anon., 2000a).Jackfruit is not easy to eat out of hand owing to difficulty in separating fruit bulbs from rind.

This difficulty has its origin in morphological and biochemical hindrances associated with the fruit. Further the fruit in fresh form are not liked by many due to its intense flavour (Bhatia et al., 1956). Therefore, it is urged 
that indigenous or underutilized fruits which are not easily marketed in the fresh form should be processed into acceptable products (Jagadeesh et al., 2007). The jackfruit is classified into two groups, one with firm to crisp flesh; generally highly flavoured, while other is generally mushy or soft fleshed (Singh, 1995). Jackfruit is nutritious, rich in vitamins ( $\mathrm{A}$ and $\mathrm{B})$, minerals $(\mathrm{Ca}, \mathrm{K}$ and $\mathrm{Fe}$ ) and contains considerable amounts of carotene and vitamin C. It is a rich source of pectin and protein (Nandini et al., 1989).

Jackfruit is a poor man's fruit which is available in plenty during the season (AprilAugust) and firm flesh bulbs are marketed and relished as dessert fruit. However, the soft flesh type does not find utility in the ripe form as it is not liked due to mashy texture. More than 60-70 per cent of the soft flesh form is wasted without utilization in the Western Ghats area where jackfruit is grown in plenty. This form being rich in sugars can be suitably used for the production of fermented beverage like wine. This endeavour helps not only to utilize the underutilized soft flesh jackfruit type but also to exploit excess produce of the jackfruit during the season. It also ensures the development of a sustained jackfruit processing cottage industry in rural areas and small towns.

\section{Materials and Methods}

\section{Total soluble solids $\left({ }^{\circ}\right.$ Brix $)$}

The total soluble solids of the wine were determined with the help of "ERMA" hand refractometer having a range of 0 to 32 ${ }^{\circ}$ Brixat room temperature.

pH

The $\mathrm{pH}$ of the wine was measured using digital $\mathrm{pH}$ meter (Model: Analog, research, USA). Standard buffer solution of $\mathrm{pH} 4.01$ and 9.08 were used as reference to calibrate the instrument.

\section{Titratable acidity (\%)}

Ten $\mathrm{ml}$ of sample was taken in a100 ml volumetric flask and the volume was made up. From this $10 \mathrm{ml}$ of aliquot was taken in a $100 \mathrm{ml}$ conical flask and titrated against $0.1 \mathrm{~N}$ $\mathrm{NaOH}$ using one or two drops of Phenolphthalein indicator. Appearance of light pink color denoted the end point. Total titratable activity was expressed as per cent citric acid.(Srivastava and Kumar, 1993)

$\%$ of acidity $=$

Titrable value $x$ Normality of $\mathrm{NaOH} x$ Vol. made up $x$ Equivalent wt. of acid

Vol. of sample for estimation $\mathrm{x}$ Weight or volume of sampel taken $\mathrm{x} 1000$

\section{Estimation of ethanol}

Determination of ethanol concentration in aqueous solutions by using alcohol meter. Alcohol meter was directly dipped in the sample taken in a $500 \mathrm{ml}$ measuring cylinder and the scale in the meter where it coincides with the meniscus of the sample indicates per cent $\mathrm{v} / \mathrm{v}$ alcohol present in the sample.

\section{Estimation of tannins}

Tannins were estimated by determining their oxidisability of potassium permanganate solution. A known volume of aliquot was taken in a porcelain dish. Indigo carmine solution $(20 \mathrm{ml}$ ) and water (about 500-750 $\mathrm{ml}$ ) were added and titrated against potassium permanganate solution until the colour turns to bright yellow or to a faint pink at the rim. Milliliters of potassium permanganate used (A) was noted.

A known volume of sample was taken and added with $25 \mathrm{ml}$ of gelatin solution and the volume was made up to $500 \mathrm{ml}$ by adding acid sodium chloride solution. From that, a 50 
$\mathrm{ml}$ sample was taken and added with $20 \mathrm{ml}$ of indigo carmine solution. Again the volume was made up to $500 \mathrm{ml}$ by adding water and titrated against potassium permanganate solution as before (B).

The amount of milliliters of $\mathrm{KMnO}_{4}$ used in this case (B) subtracted from (A) gave the quantity of $\mathrm{KMnO}_{4}$ solution required to oxdise the tannins. The percentage of tannins in the sample was calculated by the formula given below.

A: Total tannin like materials

B: Non- tannin materials

A- B: True tannins

$\%$ of tannin $=$

$\frac{\text { Titrable } \quad \text { value } \mathrm{x} g \text { of tannins } / \mathrm{m} \quad 1 \text { of } \mathrm{KMnO} 4}{\text { Vol. of sample for estimation }} \times 100$

$1 \mathrm{ml}$ of $0.1 \mathrm{~N} \mathrm{KMnO}_{4}=0.0042 \mathrm{~g}$ of tannin

\section{Results and Discussion}

\section{TSS $\left({ }^{\circ} \mathrm{B}\right)$}

In the present study, TSS of fresh jack fruit wine recorded a range from 9.00 to $10.93{ }^{\circ} \mathrm{B}$ from the initial $24^{\circ} \mathrm{B}$ (Table 1). The treatment $\mathrm{T}_{7}$ (Must with 1:2.5 dilution+3.4 $\mathrm{pH}$ ) recorded significantly lowest TSS of $9.00^{\circ} \mathrm{B}$. The highest TSS $\left(10.93{ }^{\circ} \mathrm{B}\right)$ was found in treatment $\mathrm{T}_{4}$ (Must with 1:2 dilution +3.5 $\mathrm{pH})$. The TSS content of wines decreased slightly in all the treatments during aging irrespective of the conditions of aging. Aging of resultant wines under cold condition $\left(14 \pm 1^{\circ} \mathrm{C}\right)$, resulted a significantly lower TSS $\left(8.73^{\circ} \mathrm{B}\right.$ ) in the treatment $\mathrm{T}_{7}$ (Must with $1: 2.5$ dilution+3.4 $\mathrm{pH}$ ) followed by $\mathrm{T}_{8}$ and $\mathrm{T}_{6}$ (Table1). The highest TSS of $10.31^{\circ} \mathrm{B}$ was found in treatment $\mathrm{T}_{4}$ (Must with 1:2 dilution $+3.5 \mathrm{pH})$ at 3 months and in the treatment $\mathrm{T}_{1}$ $\left(9.73^{\circ} \mathrm{B}\right)$ at 6 months. The treatment $\mathrm{T}_{7}$ continued to remain low in terms of TSS at the end of 6 months of aging. Aging under ambient condition $\left(27 \pm 1^{\circ} \mathrm{C}\right)$ resulted a lower TSS (8.71 and 8.26) in the treatment $\mathrm{T}_{8}$ (Must with $1: 2.5$ dilution+3.5 $\mathrm{pH}$ ). The highest TSS $\left(10.06^{\circ} \mathrm{B}\right.$ ) was found in treatment $\mathrm{T}_{1}$ (Must with $1: 2$ dilution $+3.2 \mathrm{pH}$ ) at 3 months and $9.44^{\circ} \mathrm{B}$ was found in $\mathrm{T}_{2}$ at 6 months of aging. The reduction in the TSS during aging of wines is expected to be due to the slower yeast activity that may still prevail during aging which converts sugars into alcohol (Owen, 2004). A corresponding increase in alcohol content of respective treatments during aging corroborates the view that sugars are fermented by yeasts to produce a little more alcohol. The jack fruit wine witnessed further but slight decrease in the TSS during ageing both in cold and ambient condition $\left(14 \pm 1^{\circ} \mathrm{C}\right.$ and $\left.27 \pm 1^{\circ} \mathrm{C}\right)$ with the same trend in all the treatments demonstrating slow activity of wine yeasts.

\section{pH}

In this study, $\mathrm{pH}$ of jack fruit must was adjusted to 3.2 to 3.5 with 2 different combinations of dilution levels. The $\mathrm{pH}$ of fresh jack fruit wine showed a slight decrease in all the treatments. The decrease in $\mathrm{pH}$ of wine in all treatments might be due to production of large amounts of acidic wastes. Wines vary considerably in $\mathrm{pH}$, with values below 3.1 being perceived as sour and those above 3.7 being perceived as flat (Jackson, 1994). Only fresh wines in the treatments $T_{4}$, $\mathrm{T}_{6}$ and $\mathrm{T}_{8}$ recorded the $\mathrm{pH}$ slightly above 3.0 with remaining treatments documenting a $\mathrm{pH}$ below 3.0 (Table 2).

However, during ageing all the treatments have recorded an increase in the $\mathrm{pH}$ values. Similar observations of increase in $\mathrm{pH}$ after fermentation and during ageing have been recorded by Shankar et al., (2004) in guava wine. After 6 months of ageing, jack fruit wine with the treatment $\mathrm{T}_{4}$ (must with 1:2 
dilution $+3.5 \mathrm{pH})$ continued to maintain the tendency to record maximum $\mathrm{pH}$ (4.09 both in cold and ambient ageing) while the minimum (3.51 and 3.79) was observed in T5 (Must with 1:2.5 dilution $+3.2 \mathrm{pH}$ ) and $\mathrm{T}_{6}$ (Must with 1:2.5 dilution $+3.3 \mathrm{pH}$ ). The degradation of arginine, one of the major amino acids in grape must and wine, releases ammonia, which may help to raise the $\mathrm{pH}$ (Jackson, 1994). Shukla et al., (1991) analysed the $\mathrm{pH}$ of the wine samples prepared from different varieties of jambalfruit and the $\mathrm{pH}$ of these wines ranged from 3.50 to 3.40 . The increase in $\mathrm{pH}$ was due to reduction in acidity through precipitation of potassium tartarate salts from wine or due to enhanced synthesis of esters from ethyl alcohol and volatile acids. The changes in the $\mathrm{pH}$ were not correlated with the changes in total acidity because of the buffering capacity of the wines and the relative amount of various acids influencing the acidity (Shankar et al., 2004).

\section{Titrable acidity (\%)}

It is important to have the perfect balance of sugar, acidity and $\mathrm{pH}$ in the must for quality wine production. Titrable acidity of wine depends upon the total organic acids content of the wine. The mean titrable acidity content of the fresh jack fruit wine was 1.10 per cent while that after 3 and 6 months of ageing under cold condition was 1.07 and 1.02 per cent respectively (Table 3 ). The decrease in the acidity during ageing might be due to combination of acids with alcohol to form esters which adds aroma to the wine during ageing (Shankar et al., 2004). The titrable acidity is an important parameter used to measure the quality of wine (Olasupo and Obayori, 2003). The ideal acidity in the wine is dependent on the style and preferences of the consumer. Nevertheless, the acceptable range for total acidity in most wines is between 5.5 and $8.5 \mathrm{mg} / \mathrm{l}(0.55$ to $0.85 \%)$. White wines are generally preferred at higher end of the scale whereas red wines are more appreciated at lower end (Jackson, 1994).

After six months of ageing in cold condition jack fruit wine showed minimum titrable acidity $\left(0.81 \%\right.$ ) in $\mathrm{T}_{8}$ (must with 1:2.5 dilution+ $3.5 \mathrm{pH}$ ) which was at par with $\mathrm{T}_{4}$ (must with 1:2 dilution+ $3.5 \mathrm{pH}$ ) and $\mathrm{T}_{6}$ (must with 1:2.5 dilution+ $3.3 \mathrm{pH}$ ). The maximum value for the parameter was observed in $\mathrm{T}_{1}$ $(1: 2$ dilution $+3.2 \mathrm{pH}))$ acidity level of 1.2 per cent which was on par with $\mathrm{T}_{1}$ and $\mathrm{T}_{2}$. After three and six months of ageing in ambient condition, the treatment $\mathrm{T}_{8}$ (must with 1:2.5 dilution+ $3.5 \mathrm{pH}$ ) recorded the minimum acidity content $(0.83$ and $0.81 \%)$ and maximum acidity (1.28and $1.26 \%$ ) was found in Treatment $\mathrm{T}_{1}(1: 2$ dilution+ $3.2 \mathrm{pH})$. The variation in the titrable acidity level due to treatment differences have been accounted in karonda wine (Bhajipale et al., 1998), mahua wine (Yadav, 2009), mango wine (Thippesha et al., 1997) and strawberry wine (Somesh et.al., 2009).

\section{Ethanol (\% V/V)}

Ethanol is undisputedly the most important alcohol in wine. Ethanol is the principal organic by-product of fermentation (Jackson, 1994). Alcohol production is one of the parameters to test the efficiency of fermentation, since alcohol is a major solvent in wine. The highest ethanol content $(8.85 \%)$ in the fresh wine was noticed in treatment $\mathrm{T}_{7}$ Must with 1:2.5 dilution $+3.4 \mathrm{pH}$ (Table 4). It can be attributed to the higher amount of available sugars and the favourable must conditions (dilution and $\mathrm{pH}$ ) for fermentation. During ageing, the alcohol level increased slightly in all the treatments. This increase might have been due to very slow fermentation that occurred during ageing. The $\mathrm{T}_{7}$ (must with $24^{0}$ Brix $\mathrm{TSS}+3.5 \mathrm{pH}$ ) treatment continued to exhibit significantly higher ethanol content (8.92, 9.01 and 9.09 
$\%$ ) after six months of ageing in cold and after three and six months of ageing in ambient condition respectively. Kotecha (2010a) recorded a similar range of alcohol content in wines of banana and ber $(7.6 \%)$, jamun $(8.4 \%)$, sapota $7.2 \%$ and strawberry (7.0\%). Somesh et al., (2009) observed a variation in the alcohol content of strawberry wine; Reddy and Reddy (2009) in mango wine; and Joshi et al., (2005) in peach wine due to variation in varieties. In some treatments, there was decrease in the alcohol content. Auto oxidation of alcohol to esters or aldehydes or due to combining ability of alcohol with acidity of wine to form esters was observed in guava wine (Shankar et al., 2004).

\section{Tannins (\%)}

Tannins are one of the important parameter in wine which gives subtle aroma and bouquet during ageing. Tannins non-significant differences among the treatments in fresh wine as well as in aged wines in all the periodical observations of ageing in both cold and ambient condition (Table 5).There was a decrease in the per cent of tannins in all the treatments, this may due to hydrolysis of poly phenols to isoprenoid (Jackson, 1994). Treatment $\mathrm{T}_{8}$ (must with 1:2.5 dilution +3.5 $\mathrm{pH}$ ) obtained the highest per cent of tannins whereas treatment $\mathrm{T}_{6}$ (Must with 1:2.5 dilution $+3.3 \mathrm{pH}$ ) recorded the lowest tannin content throughout the investigation. The per cent of tannins may vary in the treatments depending upon the type of wine, yeast fermentation conditions, containers and the maturation period was observed in litchi wine (Singh and Kaur, 2009).

\section{Wine recovery $(\%)$}

The wine recovery in this study showed significant variations due to the treatments differences. Higher wine recovery was noted at higher $(1: 2.5)$ of the two dilutions employed in the present study (Table 6). Irrespective of the dilutions, an increase in the wine recovery was found associated with higher $\mathrm{pH}$ levels. The wine recovery recorded a wide range from 45.74 to 78.13 per cent which may be attributed to the difference in the dilution and $\mathrm{pH}$ of the must. The treatment $\mathrm{T}_{8}$ (Must with 1:2.5 dilution $+3.5 \mathrm{pH}$ ) exhibited the highest recovery percentage of 78.13 followed by $T_{7}(67.72 \%)$ and $T_{6}$ $(61.94 \%)$. The variation of wine recovery in this study may be attributed to the influence of $\mathrm{pH}$ and dilution level of must on the activity of yeasts. A combination of higher must dilution (1:2.5) and higher $\mathrm{pH}$ (3.5) was found to yield more wine. Bhajipale et al., (1998) in karonda wine; and Saravana et al., (2001) in strawberry reported differences in wine yield due to treatment differences.

\section{Colour (OD value)}

The colour of jack fruit wine as represented by OD values in fresh wine and after ageing in both ambient and cold conditions showed non-significant variation among the treatments. Higher OD values indicate lower transmission and in turn lower brightness and clarity. Table 7 shows the treatment $\mathrm{T}_{8}$ (Must with 1:2.5 dilution $+3.5 \mathrm{pH}$ ) obtained higher OD value of 1.56 under cold aging conditions while $\mathrm{T}_{3}$ (Must with 1:2 dilution $+3.4 \mathrm{pH}$ ) after 6 months of ageing under ambient condition. The lowest OD value of 1.07 and 1.08 were associated with $\mathrm{T}_{2}$ at 3 months of aging under both the conditions. However, at 6 months of aging the least OD of 1.07 and 0.98 was noticed in treatment $\mathrm{T}_{6}$ (Must with $1: 2.5$ dilution $+3.3 \mathrm{pH}$ ) and $\mathrm{T}_{1}$ (Must with $1: 2$ dilution $+3.2 \mathrm{pH}$ ) respectively under cold and ambient conditions. The greater wine clarity allows for more transmission of light resulting in smaller OD value whereas deeper colour of wine allows lesser transmission of light and increased OD value. 
Table.1 Effect of 'must dilution and $\mathrm{pH}$ ' on Total soluble solids ( $\left.{ }^{\mathrm{O}} \mathrm{Brix}\right)$ of fresh jack fruit wine and after ageing

\begin{tabular}{|c|c|c|c|c|c|c|c|}
\hline \multirow{3}{*}{$\begin{array}{l}\text { Tr. } \\
\text { No }\end{array}$} & \multirow[t]{3}{*}{ Treatment details } & \multicolumn{6}{|c|}{ TSS ( ${ }^{0}$ Brix $)$} \\
\hline & & \multirow[t]{2}{*}{ Must } & \multirow[t]{2}{*}{ Fresh wine } & \multicolumn{2}{|c|}{ Ageing in cold } & \multicolumn{2}{|c|}{ Ageing in ambient } \\
\hline & & & & $3 \mathrm{MA}$ & $6 \mathrm{MA}$ & $3 \mathrm{MA}$ & $6 \mathrm{MA}$ \\
\hline $\mathbf{T}_{1}$ & Must with $1: 2$ dilution $+3.2 \mathrm{pH}$ & & 10.36 & 9.89 & 9.73 & 10.06 & 9.26 \\
\hline $\mathbf{T}_{2}$ & Must with $1: 2$ dilution $+3.3 \mathrm{pH}$ & & 10.13 & 9.70 & 9.33 & 10.03 & 9.44 \\
\hline $\mathbf{T}_{\mathbf{3}}$ & Must with $1: 2$ dilution $+3.4 \mathrm{pH}$ & & 10.46 & 9.73 & 9.13 & 9.86 & 9.20 \\
\hline $\mathbf{T}_{4}$ & Must with $1: 2$ dilution $+3.5 \mathrm{pH}$ & & 10.93 & 10.32 & 9.26 & 9.76 & 8.80 \\
\hline $\mathbf{T}_{5}$ & Must with $1: 2.5$ dilution $+3.2 \mathrm{pH}$ & & 10.73 & 9.80 & 9.47 & 9.83 & 8.60 \\
\hline $\mathbf{T}_{6}$ & Must with $1: 2.5$ dilution $+3.3 \mathrm{pH}$ & & 9.30 & 9.20 & 9.07 & 9.20 & 8.76 \\
\hline $\mathbf{T}_{7}$ & Must with $1: 2.5$ dilution $+3.4 \mathrm{pH}$ & & 9.00 & 8.70 & 8.41 & 8.73 & 8.60 \\
\hline \multirow[t]{4}{*}{$\mathbf{T}_{8}$} & Must with $1: 2.5$ dilution $+3.5 \mathrm{pH}$ & & 9.03 & 9.00 & 8.67 & 8.71 & 8.26 \\
\hline & Mean & 24 & 9.99 & 9.54 & 9.13 & 9.52 & 8.86 \\
\hline & S.Em \pm & - & 0.15 & 0.08 & 0.09 & 0.05 & 0.08 \\
\hline & CD $1 \%$ & - & 0.48 & 0.27 & 0.29 & 0.19 & 0.26 \\
\hline
\end{tabular}

3MA -3 months of ageing 6MA - 6 months of ageing

Ageing in cold at $14 \pm 1^{\circ} \mathrm{C}$; Ageing in ambient condition $27 \pm 1^{\circ} \mathrm{C}$

Table.2 Effect of 'must dilution and $\mathrm{pH}$ ' on $\mathrm{pH}$ of fresh jack fruit wine and after ageing

\begin{tabular}{|c|c|c|c|c|c|c|}
\hline \multirow{3}{*}{$\begin{array}{l}\text { Tr. } \\
\text { No }\end{array}$} & \multirow[t]{3}{*}{ Treatment details } & \multicolumn{5}{|c|}{$\mathbf{p H}$} \\
\hline & & \multirow[t]{2}{*}{ Fresh wine } & \multicolumn{2}{|c|}{ Ageing in cold } & \multicolumn{2}{|c|}{ Ageing in ambient } \\
\hline & & & 3MA & $6 \mathrm{MA}$ & $3 \mathrm{MA}$ & $6 \mathrm{MA}$ \\
\hline $\mathbf{T}_{1}$ & Must with $1: 2$ dilution $+3.2 \mathrm{pH}$ & 2.54 & 3.62 & 3.95 & 3.56 & 3.81 \\
\hline $\mathbf{T}_{2}$ & Must with $1: 2$ dilution $+3.3 \mathrm{pH}$ & 2.71 & 3.56 & 3.93 & 3.76 & 3.89 \\
\hline $\mathbf{T}_{\mathbf{3}}$ & Must with $1: 2$ dilution $+3.4 \mathrm{pH}$ & 2.84 & 3.96 & 4.05 & 3.87 & 3.94 \\
\hline $\mathbf{T}_{4}$ & Must with $1: 2$ dilution $+3.5 \mathrm{pH}$ & 3.15 & 3.98 & 4.09 & 3.99 & 4.09 \\
\hline $\mathbf{T}_{5}$ & Must with $1: 2.5$ dilution $+3.2 \mathrm{pH}$ & 2.82 & 3.46 & 3.51 & 3.68 & 3.81 \\
\hline $\mathbf{T}_{6}$ & Must with $1: 2.5$ dilution $+3.3 \mathrm{pH}$ & 3.11 & 3.24 & 3.83 & 3.54 & 3.79 \\
\hline $\mathbf{T}_{7}$ & Must with $1: 2.5$ dilution $+3.4 \mathrm{pH}$ & 2.81 & 3.63 & 4.02 & 3.88 & 4.04 \\
\hline \multirow{4}{*}{$\mathbf{T}_{8}$} & Must with $1: 2.5$ dilution $+3.5 \mathrm{pH}$ & 3.26 & 3.88 & 4.01 & 3.94 & 4.13 \\
\hline & Mean & 2.91 & 3.66 & 3.92 & 3.77 & 3.93 \\
\hline & SEm \pm & 0.04 & 0.08 & 0.04 & $\mathbf{0 . 0 3}$ & 0.10 \\
\hline & CD $1 \%$ & 0.14 & 0.26 & 0.14 & 0.12 & 0.21 \\
\hline
\end{tabular}


Table.3 Effect of 'must dilution' and $\mathrm{pH}$ on Titrable acidity (\%)of fresh jack fruit wine and after ageing

\begin{tabular}{|l|l|l|l|l|l|l|}
\hline \multirow{2}{*}{$\begin{array}{l}\text { Tr. } \\
\text { No }\end{array}$} & Treatment details & \multicolumn{5}{|c|}{ Titrable acidity (\%) } \\
\cline { 4 - 7 } & & Fresh & Ageing in cold & \multicolumn{2}{|c|}{ Ageing in ambient } \\
\hline T1 & Must with 1:2 dilution $+3.2 \mathrm{pH}$ & 1.31 & 1.29 & 1.24 & 1.28 & 1.24 \\
\hline T2 & Must with 1:2 dilution $+3.3 \mathrm{pH}$ & 1.19 & 1.15 & 1.12 & 1.06 & 1.12 \\
\hline T3 & Must with 1:2 dilution $+3.4 \mathrm{pH}$ & 1.08 & 1.06 & 1.01 & 1.07 & 1.01 \\
\hline T4 & Must with 1:2 dilution $+3.5 \mathrm{pH}$ & 1.01 & 0.98 & 0.91 & 0.99 & 0.91 \\
\hline T5 & Must with 1:2.5 dilution $+3.2 \mathrm{pH}$ & 1.09 & 1.07 & 1.02 & 1.04 & 1.02 \\
\hline T6 & Must with 1:2.5 dilution $+3.3 \mathrm{pH}$ & 0.98 & 0.94 & 0.89 & 0.97 & 0.89 \\
\hline T7 & Must with 1:2.5 dilution $+3.4 \mathrm{pH}$ & 1.26 & 1.21 & 1.19 & 1.21 & 1.19 \\
\hline T8 & Must with 1:2.5 dilution $+3.5 \mathrm{pH}$ & 0.87 & 0.85 & 0.81 & 0.83 & 0.81 \\
\hline & Mean & $\mathbf{1 . 1 0}$ & $\mathbf{1 . 0 7}$ & $\mathbf{1 . 0 2}$ & $\mathbf{1 . 0 6}$ & $\mathbf{1 . 0 3}$ \\
\hline & SEm \pm & $\mathbf{0 . 0 5}$ & $\mathbf{0 . 0 3}$ & $\mathbf{0 . 0 4}$ & $\mathbf{0 . 0 6}$ & $\mathbf{0 . 0 4}$ \\
\hline & CD 1\% & $\mathbf{0 . 1 6}$ & $\mathbf{0 . 1 1}$ & $\mathbf{0 . 1 7}$ & $\mathbf{0 . 2 1}$ & $\mathbf{0 . 1 5}$ \\
\hline
\end{tabular}

3MA -3 months of ageing 6MA - 6 months of ageing

Ageing in cold at $14 \pm 1^{\circ} \mathrm{C}$; Ageing in ambient condition $27 \pm 1^{\circ} \mathrm{C}$

Table.4 Effect of 'must dilution and pH' on Ethanol (\%) of fresh jack fruit wine and after its ageing

\begin{tabular}{|c|c|c|c|c|c|c|}
\hline \multirow{3}{*}{$\begin{array}{l}\text { Tr. } \\
\text { No }\end{array}$} & \multirow[t]{3}{*}{ Treatment details } & \multicolumn{5}{|c|}{ Alcohol (\%) } \\
\hline & & \multirow[b]{2}{*}{ Fresh wine } & \multicolumn{2}{|c|}{ Ageing in cold } & \multicolumn{2}{|c|}{ Ageing in ambient } \\
\hline & & & $3 \mathrm{MA}$ & 6MA & $3 \mathrm{MA}$ & $6 \mathrm{MA}$ \\
\hline$T_{1}$ & Must with $1: 2$ dilution $+3.2 \mathrm{pH}$ & 7.68 & 8.04 & 8.42 & 8.23 & 8.54 \\
\hline $\mathbf{T}_{2}$ & Must with $1: 2$ dilution $+3.3 \mathrm{pH}$ & 7.89 & 8.44 & 8.65 & 8.24 & 8.31 \\
\hline $\mathbf{T}_{3}$ & Must with $1: 2$ dilution $+3.4 \mathrm{pH}$ & 7.69 & 8.13 & 8.77 & 8.34 & 8.39 \\
\hline $\mathbf{T}_{4}$ & Must with $1: 2$ dilution $+3.5 \mathrm{pH}$ & 7.45 & 7.30 & 8.70 & 8.40 & 8.46 \\
\hline $\mathbf{T}_{5}$ & Must with $1: 2.5$ dilution $+3.2 \mathrm{pH}$ & 7.54 & 8.09 & 8.59 & 8.36 & 8.29 \\
\hline$T_{6}$ & Must with $1: 2.5$ dilution $+3.3 \mathrm{pH}$ & 8.38 & 8.43 & 8.80 & 8.73 & 8.36 \\
\hline $\mathbf{T}_{7}$ & Must with $1: 2.5$ dilution $+3.4 \mathrm{pH}$ & 8.85 & 8.70 & 8.92 & 9.01 & 9.09 \\
\hline \multirow[t]{4}{*}{$\mathbf{T}_{8}$} & Must with $1: 2.5$ dilution $+3.5 \mathrm{pH}$ & 8.08 & 8.85 & 8.04 & 8.86 & 8.94 \\
\hline & Mean & 7.94 & 8.24 & 8.61 & 8.52 & 8.54 \\
\hline & SEm \pm & 0.16 & 0.15 & 0.12 & 0.19 & 0.20 \\
\hline & CD 1\% & 0.52 & 0.49 & 0.41 & 0.59 & 0.63 \\
\hline
\end{tabular}

$3 \mathrm{MA}-3$ months of ageing $6 \mathrm{MA}-6$ months of ageing

Ageing in cold at $14 \pm 1^{\circ} \mathrm{C}$; Ageing in ambient condition $27 \pm 1^{\circ} \mathrm{C}$ 
Table.5 Effect of 'must dilution and $\mathrm{pH}$ on Tannins' (\%) of fresh jack fruit wine and after ageing

\begin{tabular}{|c|c|c|c|c|c|c|}
\hline \multirow{3}{*}{$\begin{array}{l}\text { Tr. } \\
\text { No }\end{array}$} & \multirow[t]{3}{*}{ Treatment details } & \multicolumn{5}{|c|}{ Tannins (\%) } \\
\hline & & \multirow[t]{2}{*}{ Fresh wine } & \multicolumn{2}{|c|}{ Ageing in cold } & \multicolumn{2}{|c|}{ Ageing in ambient } \\
\hline & & & 3MA & $6 \mathrm{MA}$ & $3 \mathrm{MA}$ & $6 \mathrm{MA}$ \\
\hline $\mathbf{T}_{1}$ & Must with $1: 2$ dilution $+3.2 \mathrm{pH}$ & 0.10 & 0.09 & 0.09 & 0.10 & 0.09 \\
\hline $\mathbf{T}_{2}$ & Must with $1: 2$ dilution $+3.3 \mathrm{pH}$ & 0.14 & 0.11 & 0.10 & 0.13 & 0.11 \\
\hline $\mathbf{T}_{3}$ & Must with $1: 2$ dilution $+3.4 \mathrm{pH}$ & 0.12 & 0.10 & 0.09 & 0.12 & 0.09 \\
\hline $\mathbf{T}_{4}$ & Must with $1: 2$ dilution $+3.5 \mathrm{pH}$ & 0.11 & 0.11 & 0.09 & 0.10 & 0.08 \\
\hline $\mathbf{T}_{5}$ & Must with $1: 2.5$ dilution $+3.2 \mathrm{pH}$ & 0.09 & 0.07 & 0.07 & 0.09 & 0.09 \\
\hline$T_{6}$ & Must with $1: 2.5$ dilution $+3.3 \mathrm{pH}$ & 0.07 & 0.05 & 0.04 & 0.07 & 0.06 \\
\hline $\mathbf{T}_{7}$ & Must with $1: 2.5$ dilution $+3.4 \mathrm{pH}$ & 0.17 & 0.16 & 0.12 & 0.17 & 0.14 \\
\hline \multirow[t]{4}{*}{$\mathbf{T}_{8}$} & Must with $1: 2.5$ dilution $+3.5 \mathrm{pH}$ & 0.19 & 0.17 & 0.13 & 0.19 & 0.16 \\
\hline & Mean & 0.99 & 0.86 & 0.73 & 0.97 & 0.82 \\
\hline & SEm \pm & 0.08 & 0.04 & 0.06 & 0.05 & 0.07 \\
\hline & CD 1\% & NS & NS & NS & NS & NS \\
\hline
\end{tabular}

$3 \mathrm{MA}-3$ months of ageing $6 \mathrm{MA}-6$ months of ageing

Ageing in cold at $14 \pm 1^{\circ} \mathrm{C}$; Ageing in ambient condition $27 \pm 1^{\circ} \mathrm{C}$

Table.6 Effect of 'must dilution and $\mathrm{pH}$ ' on wine recovery (\%) of fresh jackfruit wine after fermentation

\begin{tabular}{|l|c|c|}
\hline Tr. No & Treatment details & Wine recovery (\%) \\
\cline { 3 - 3 } & & Fresh wine \\
\hline $\mathbf{T}_{\mathbf{1}}$ & Must with 1:2 dilution $+3.2 \mathrm{pH}$ & 50.743 \\
\hline $\mathbf{T}_{\mathbf{2}}$ & Must with 1:2 dilution $+3.3 \mathrm{pH}$ & 45.743 \\
\hline $\mathbf{T}_{\mathbf{3}}$ & Must with 1:2 dilution $+3.4 \mathrm{pH}$ & 51.670 \\
\hline $\mathbf{T}_{\mathbf{4}}$ & Must with 1:2 dilution $+3.5 \mathrm{pH}$ & 54.260 \\
\hline $\mathbf{T}_{\mathbf{5}}$ & Must with 1:2.5 dilution $+3.2 \mathrm{pH}$ & 57.960 \\
\hline $\mathbf{T}_{\mathbf{6}}$ & Must with 1:2.5 dilution $+3.3 \mathrm{pH}$ & 61.946 \\
\hline $\mathbf{T}_{\mathbf{7}}$ & Must with 1:2.5 dilution $+3.4 \mathrm{pH}$ & 67.720 \\
\hline $\mathbf{T}_{\mathbf{8}}$ & Must with 1:2.5 dilution $+3.5 \mathrm{pH}$ & 78.130 \\
\hline & Mean & $\mathbf{5 8 . 5 2}$ \\
\hline & SEm \pm & $\mathbf{2 . 8 9}$ \\
\hline
\end{tabular}


Table.7 Effect of 'must dilution and $\mathrm{pH}$ ' on colour(OD value) of fresh jack fruit wine and after ageing

\begin{tabular}{|c|c|c|c|c|c|c|}
\hline \multirow{3}{*}{$\begin{array}{l}\text { Tr. } \\
\text { No }\end{array}$} & \multirow[t]{3}{*}{ Treatment details } & \multicolumn{5}{|c|}{ Colour (OD value) } \\
\hline & & \multirow[t]{2}{*}{ Fresh wine } & \multicolumn{2}{|c|}{ Ageing in cold } & \multicolumn{2}{|c|}{ Ageing in ambient } \\
\hline & & & 3MA & $6 \mathrm{MA}$ & $3 \mathrm{MA}$ & $6 \mathrm{MA}$ \\
\hline T1 & Must with $1: 2$ dilution $+3.2 \mathrm{pH}$ & 1.00 & 1.08 & 1.33 & 1.05 & 0.98 \\
\hline $\mathbf{T} 2$ & Must with $1: 2$ dilution $+3.3 \mathrm{pH}$ & 1.00 & 1.07 & 1.38 & 1.08 & 1.12 \\
\hline T3 & Must with $1: 2$ dilution $+3.4 \mathrm{pH}$ & 1.00 & 1.36 & 1.08 & 1.34 & 1.67 \\
\hline $\mathbf{T 4}$ & Must with $1: 2$ dilution $+3.5 \mathrm{pH}$ & 1.00 & 1.20 & 1.32 & 1.26 & 1.27 \\
\hline T5 & Must with $1: 2.5$ dilution $+3.2 \mathrm{pH}$ & 1.20 & 1.39 & 1.38 & 1.28 & 1.34 \\
\hline T6 & Must with $1: 2.5$ dilution $+3.3 \mathrm{pH}$ & 1.00 & 1.17 & 1.07 & 1.17 & 1.14 \\
\hline T7 & Must with $1: 2.5$ dilution $+3.4 \mathrm{pH}$ & 1.00 & 1.18 & 1.50 & 1.23 & 1.02 \\
\hline \multirow[t]{4}{*}{ T8 } & Must with $1: 2.5$ dilution $+3.5 \mathrm{pH}$ & 1.20 & 1.33 & 1.56 & 1.17 & 1.24 \\
\hline & Mean & 1.10 & 1.33 & 1.23 & 1.20 & 1.23 \\
\hline & $\mathrm{SEm} \pm$ & 0.07 & 0.09 & 0.20 & 0.90 & 0.14 \\
\hline & CD $1 \%$ & NS & NS & NS & NS & NS \\
\hline
\end{tabular}

A slight but insignificant variation in wine colour observed in this study may have its roots in the biochemical interaction between the sugars, $\mathrm{pH}$ and other constituents of pulp, in addition to the effect of conditions on fermentation and ageing.

Joshi et al., (2005) observed a variation in the colour intensity of wine made from peach cultivars where in the higher colour intensity was recorded in cv. Redhaven (OD of 0.19) and lower in cv. Stark Early Gaint (OD of 0.86). The change in colour of wine made from guavas at different stages of maturity was attributed to variation in the pigmentation of fruits (Anderson and Badrie, 2005).

Aging process is primarily physico-chemical; higher temperature speeds and activates most of the reactions involved. For most wines, prolonged exposure to temperatures of $40^{\circ} \mathrm{C}$ or more results in deterioration in quality. Carbohydrates in the wine undergo Maillard and thermal degradation reactions turning the wine brown (Jackson, 1994). The two temperatures adapted in the present study did not reveal much colour change as even the higher temperature was much below the deleterious temperature $\left(40^{\circ} \mathrm{C}\right)$.

\section{References}

Andrerson, C. and Badrie, N. 2005, Physicochemical quality and consumer acceptance of guava wines. Haryana J. Hort. Sci.,42(3): 223-226.

Anonymous., 2000, Horticultural Crop Statistics of Karnataka State at a Glance, Government of Karnataka, Directorate of Horticulture, Lal Bagh, Bangalore., pp. 86-87.

Bhajipale, B.J., Gupta D.N. and Mehta, 1998, Effect of different stages of ripening of fruit of karonda wine. Indian Food Packer, 54: 27-30.

Bhatia B.S., Siddappa, G.S. and Giridhari L.L., 1956, Development of fruit product: Dried jack seeds and flour, roasted nuts and jack papad. Indian Food Packer, 10: 30.

Bhatia, B.S. and Siddappa, G.S., 1955, Development production from jackfruit. Part I. Indian Food Packer, 9: 7.

Jagadeesh, S.L., Kirankumar, G., Hegde, L., 
Swamy, G.S.K., Reddy, B.S., Basavaraj, N. and Raghavan, S.V., 2007, Variability studies in physicochemical parameters in Chips purpose jackfruit selection of hilly zone in Karnataka. 2007, Karnataka J. Agric. Sci., 20(2): 346-349.

Joshi, V.K., Sharma, S. And Bhushan, S. 2005, Effect of method of preparation and cultivar on the quality of strawberry wine. Acta Aliniment., 34(4): 339-355.

Kotecha, P.M., 2010a, Composition, quality and legal requirements of wine, pp. 121127. Compendium of winter school on value addition of grapes with special reference to wine making at Rahuri (Maharshtra), 5-25 feb 10, p. 1-198.

Nandini, P.V. and Dommen, B.E., 1989, Quality parameters of selected mango cultivars. J. Food Sci. Technol., 39: 379-383.

Olasupo, N.A. and Obayori, O.S., 2003, Utilization of palm wine (Elaeis guinensis) for the improved production of Nigerian indigenous alcoholic drink Ogogoro. J. Food Pro. Preserv.,27: 365-372.

Owen, S.G., Majeed, M., Lawrence, A.W. and Linda, D.W., 2004, effects of pectolytic enzymes and anti-oxidants on the quality of dry wines made from pineapple (Ananas comosus. L. Merr) peel. Food Agric, and Envi ,2(2):135142.

Saravana, K., Manimegalai, R.G. and Hamaran, M., 2001, Wine preparation from strawberry. Beverage and Food World., pp. 18-19.

Shankar, S., Dilip, J. and Narayana, Y., 2004, Changes in chemical composition of guava wine during storage. Indian Food Packer, 12:56-58.

Shukla, K..G., Joshi, M.C., Yadav, S. and Bisht, N.S., 1991, Jambal wine making: standardization of a methodology and screening of cultivars. J. Food. Sci.Technol., 28: 142-144.

Somesh, S., Joshi, V.K. and Ghanshyam, A., 2009, An overview on strawberry wine production technology, Composition, maturation and quality evaluation. Natural Product Radiance, 8(4): 356365.

Srivastava, R.P. and Kumar, S., 1993, Important methods for analysis of fruits and vegetable and their products. Fruit and Vegetable Preservation Principles and Practices. $2^{\text {nd }}$ ed. pp. 321-339.

\section{How to cite this article:}

Anil. S. K., Praveen Gidagiri and Praveen Jholgikar. 2020. Study on Optimization of Must and Fermentation Conditions for Production of Jack Fruit (Artocarpus heterophyllus L.) Wine. Int.J.Curr.Microbiol.App.Sci. 9(06): 438-447. doi: https://doi.org/10.20546/ijcmas.2020.906.058 